\title{
Livestock depredation and mitigation methods practised by resident and nomadic pastoralists around Waza National Park, Cameroon
}

\author{
Pricelia N. Tumenta, Hans H. De Iongh, Paul J. Funston \\ and Helias A. Udo de HaEs
}

\begin{abstract}
Conflict between humans and lions Panthera leo is a key factor driving population declines of lions in Africa, especially in communal lands and on the edges of small protected areas. We assessed this conflict in Waza National Park, Cameroon, in 2008 through an interview survey. A total of 207 resident and 174 nomadic pastoralists were interviewed. Results indicated high levels of livestock depredation around the Park, with attacks occurring most often at night. Lions were economically a substantial threat accounting for total losses of EUR 100,000 per annum. Per household, resident pastoralists lost one cow and nomadic pastoralists two cows per annum, equating to c. EUR 260 and 520, respectively. To mitigate these losses resident pastoralists used enclosures for nocturnal protection of their livestock more than nomadic pastoralists, who tended to herd livestock more during pasture. Improved mitigation methods pertaining to herding practice, the use of enclosures and the presence of dogs resulted in a reduction of $25 \%$ livestock depredation and 50\% cattle depredation. These methods could be further improved, however, education and awareness about the ranging behaviour of lions during different seasons and periods of the day is important for all pastoralists. Additionally, park management needs to be improved through effective law enforcement.
\end{abstract}

Keywords Cameroon, human-lion conflict, mitigation methods, Panthera leo, predation incidence, Waza National Park

\section{Introduction}

T ivestock depredation by large carnivores is a widespread $\_$problem in Africa and undermines conservation efforts

\footnotetext{
Pricelia N. Tumenta ${ }^{*} \dagger$ (Corresponding author), Hans H. DE IONGH and Helias A. Udo DE HAES Institute of Environmental Sciences, Leiden University, P.O. Box 9518, 2300RA Leiden, The Netherlands. E-mail tumentap@yahoo.com

Paul J. Funston Department of Nature Conservation, Tshwane University of Technology, Pretoria, South Africa

${ }^{*}$ Also at: Centre for Environment and Development Studies in Cameroon, Maroua, and Department of Forestry, University of Dschang, Dschang, Cameroon

†Current address: Department of Forestry, Faculty of Agronomy and Agricultural Sciences, University of Dschang, Dschang, Cameroon

Received 13 June 2011. Revision requested 25 August 2011.

Accepted 29 September 2011.
}

in many protected areas. Globally, large carnivore numbers are declining rapidly, often as a direct result of conflict over livestock (Ogada et al., 2003; Treves \& Karanth, 2003; Patterson et al., 2004; Woodroffe \& Frank, 2005; Bauer et al., 2008), although poaching, habitat degradation and excessive trophy hunting are also serious problems (Henschel et al., 2010; Bennett, 2011; Packer et al., 2011). Lions Panthera leo suffer these problems perhaps more than other African large carnivores, and some populations have been reduced to the brink of extinction, necessitating intense conservation efforts (De Iongh et al., 2009). This is particularly the case in the savannahs of Central and West Africa, where lion populations are small and highly fragmented (Bauer et al., 2003; Bauer \& Nowell, 2004), and are disappearing at an alarming rate (Henschel et al., 2010). In semi-arid regions of sub-Saharan Africa drought conditions precipitate frequent intrusions by pastoralists, with their livestock, into protected areas holding water and pasture. A secondary but important background factor driving conflict is the depletion of the natural prey of lions (Packer, 2007; De Iongh \& Bauer, 2008), making lions more dependent on livestock.

Various conservation measures have been employed to prevent and resolve conflict between humans and threatened predators, including compensation schemes, fencing of protected areas and focused livestock husbandry practices. In some cases compensation measures facilitate conflict mitigation (Mishra et al., 2003; Verdade \& Campos, 2004) but successes with this management tool have been mixed (Nyhus et al., 2003). Fencing helps keep predators from moving out of protected areas but fences can have a negative impact on both prey (Ben Shahar, 1992) and predator (Van Dyk \& Slotow, 2003) populations. Compensation and fencing are both costly and may not be feasible in parts of Africa where little capital is being invested into conservation efforts (Blom, 2001). Thus husbandry practices and effective park management seem to be the most likely solutions to mitigate conflict in many areas.

Reviews of husbandry practices to mitigate conflicts with predators have shown that livestock depredation can be substantially reduced (Ogada et al., 2003; Frank et al., 2005; Packer 2007; Woodroffe et al., 2007; Bauer et al., 2010). Successful measures include the presence of dogs both at pasture and enclosures at night, herding smaller livestock herds by adults instead of by children (Packer, 2007), bomas with thick walls and few outlets, and high human activity at 


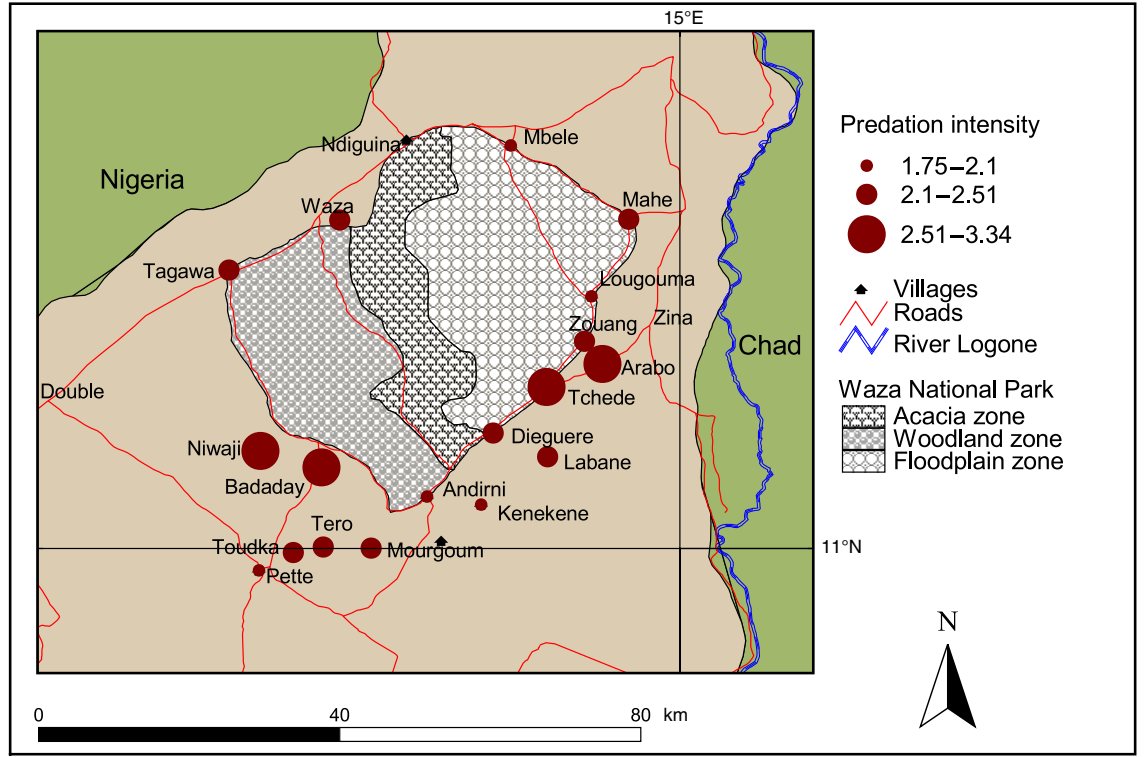

FIG. 1 Waza National Park in northern Cameroon, showing the mean number of livestock (predation intensity) lost to lion predation per locality per annum. bomas (Frank et al., 2005). In contrast to East and Southern Africa, limited knowledge exists for West and Central Africa on methods that can successfully mitigate livestock depredation (Bauer et al., 2010). Thus human-lion conflict has continued to intensify in the region, and threatens the persistence of lions in this area, including Waza National Park (De Iongh et al., 2009; Tumenta et al., 2010). The Waza lion population seems to be more vulnerable to threats given its small size and relative isolation from other populations. This prompted further investigation of livestock depredation, and the methods practised by pastoralists to mitigate the conflict. This study was designed to derive information from both resident and nomadic pastoralists that use the Waza area.

\section{Study area}

The $1,700 \mathrm{~km}^{2}$ Waza National Park lies within the Waza Logone area, near the Logone River in the Lake Chad depression (Fig. 1). The climate is Sudano-Sahelian, semiarid tropical, with three seasons: rainy (June-October), cold dry (November-February) and hot dry (March-May). Rainfall in this area is low and irregular between years, with a mean annual rainfall of $600 \mathrm{~mm}$ (Beauvilain, 1995). Temperatures range from $15^{\circ} \mathrm{C}$ (January mean minimum) to $48^{\circ} \mathrm{C}$ (April mean maximum). There is no permanent flowing water but a number of natural and artificial water reservoirs that fill during the rainy season, some of which retain water throughout the dry season. The eastern half of the Park is periodically inundated during the rainy season, flooded by excess water from the Logone River, and its branches Logomatya and Lorome Mazra. The area including Waza National Park holds water and pasture regrowth into the dry season, when water in the surrounding grassland is completely dried out. For this reason, many pastoralists enter this area with their livestock for 6-8 months each year, for water and pasture (Scholte, 2005). This results in a high concentration of livestock around the Park, with frequent intrusions.

\section{Methods}

The primary method of data collection was structured interview surveys (Piran et al., 2005). Being a self-reporting measure it is possible that some biases may be incurred either from the interviewer or respondent. As a preparatory step meetings were held to raise awareness on research activities in the area and to identify villages involved in livestock rearing. Maps of lion movements produced from global positioning system radio-collars fitted on lions, guided the selection of villages for the survey. Structured interviews were held with 207 residents in villages, and 174 nomadic pastoralists in camps, in 22 localities around Waza National Park. Camps located within $2 \mathrm{~km}$ of villages were considered the same locality. Not all localities surveyed had communities of both nomadic and resident pastoralists. In small villages and nomadic camps all livestock owners were interviewed, whereas in larger villages c. $50 \%$ of the livestock-owning population was interviewed. Household interviews were carried out by two agricultural engineering students from the University of Dschang, Cameroon, accompanied by interpreters who spoke the local languages.

The interview covered the incidence of predation by large carnivores on livestock during different seasons and at different times of day. Further questions on husbandry practices assessed whether livestock were herded by day, and whether they were confined by night. Other factors responsible for livestock loss around the Park were also investigated. Data were analysed using SPSS v. 16.0 (SPSS, Chicago, USA). An ANOVA was used to test the 
effectiveness of predation mitigation methods practised by pastoralists around Waza National Park. Differences in husbandry methods practised by the different groups of pastoralists were tested with the $\chi^{2}$ test. Regression analysis was used to establish the relationship between number of shepherds per herd and incidence of livestock depredation.

\section{Results}

Resident and nomadic pastoralists differed significantly $(\mathrm{P}<0.01)$ in the average number of individuals and number of huts per family, and in the number of livestock owned (Table 1). A total of 55,845 livestock were recorded in the area during the survey. Although predation on livestock occurred in all localities surveyed (Fig. 1) some were more affected than others. Localities west and east of Waza National Park experienced intense predation of a magnitude similar to localities south of the Park. Only two of the 22 localities surveyed experienced low predation. Three predator species were responsible for livestock depredation around the Park, namely lions, spotted hyaenas Crocuta crocuta and jackals Canis aureus. The main livestock species predated were cattle, sheep and goats (Table 2).

Spotted hyaenas were reported to be responsible for most attacks on livestock $(50 \%, \mathrm{n}=2,248)$, followed by jackals (28\%), and lions (22\%). However, lions predated more cattle, whereas hyaenas predated mainly sheep and jackals mostly goats (Table 2). Lions accounted for the highest financial losses (EUR 100,000 per annum or EUR 260 per household per annum). Predation on livestock was significantly higher for nomadic compared to resident pastoralists (Table 3). Losses of cattle were in the ratio $1: 2$ for resident and

TABLE 1 Characteristics of resident and nomadic pastoralists around Waza National Park (Fig. 1) in 2008.

\begin{tabular}{llc}
\hline Characteristic & Resident $(\mathrm{n}=207)$ & Nomadic $(\mathrm{n}=174)$ \\
\hline Family size & 12 & 10 \\
Number of huts & 6 & 4 \\
Mixed herd size & 84 & 218 \\
$\quad$ Sheep & 18 & 32 \\
Goats & 14 & 72 \\
Cattle & 52 & 114 \\
\hline
\end{tabular}

TABLE 2 Numbers of cattle, sheep and goats (with percentages in parentheses) predated per annum by lions, spotted hyaenas and jackals around Waza National Park (Fig. 1) in 2008.

\begin{tabular}{|c|c|c|c|c|}
\hline Predator & Cattle & Sheep & Goats & Total \\
\hline Lion Panthera leo & $425(84)$ & $62(12)$ & $22(4)$ & $509(100)$ \\
\hline $\begin{array}{l}\text { Spotted hyaena } \\
\text { Crocuta crocuta }\end{array}$ & $91 \quad(8)$ & $799(72)$ & $227(20)$ & $1,117(100)$ \\
\hline $\begin{array}{l}\text { Jackal Canis } \\
\text { aureus }\end{array}$ & $0 \quad(0)$ & $85(14)$ & $537(86)$ & $622(100)$ \\
\hline
\end{tabular}

nomadic pastoralists, respectively. Irrespective of type of pastoralist, predation was significantly higher during the night than during the day $(\mathrm{F}=54.1, \mathrm{df}=1, \mathrm{P}<0.01)$. Nomadic pastoralists experienced a mean loss of six livestock per annum during the night compared to a mean loss of two during the day $(\mathrm{F}=14.8, \mathrm{df}=1, \mathrm{P}<0.01)$ per household. Predation incidence per household or herder was similar during the wet (three livestock) and dry seasons (four).

In addition to predation ( $4 \%$ per annum) as a cause of livestock loss, there were losses to disease (4\%) and theft (3\%). Translated into financial terms, loss to disease ranked highest (EUR 175,000), followed by theft (EUR 161,000) and predation (EUR 150,000). Although predation ranked last economically it was perceived as the most serious threat to livestock production by $70 \%(n=381)$ of the respondents.

Both resident and nomadic pastoralists practised some traditional husbandry methods to minimize depredation of their livestock. These included herding (60.9\%), the use of enclosures to keep livestock at night (26.8\%), and the use of dogs (42.3\%) to alert the approach of predators. Herding was practised significantly more $\left(\chi^{2}=1.9, \mathrm{df}=1, \mathrm{P}<0.01\right)$ by nomadic than by resident pastoralists. Among resident pastoralists that herded their livestock $42 \%(n=60)$ of the herders were adults, whereas among nomadic pastoralists $72 \%(\mathrm{n}=124)$ were adults. A significant difference existed $\left(\chi^{2}=16.2, \mathrm{df}=1, \mathrm{P}<0.01\right)$ between herds that were herded by adults and those herded by children. Resident pastoralists experienced a mean loss of two heads of livestock per household per annum for herds herded by adults, compared to a mean loss of eight for herds herded by children. Nomadic pastoralists experienced a mean loss of five heads of livestock per household per annum for herds herded by adults compared to a loss of 16 for herds herded by children. For nomadic pastoralists predation decreased as the number of shepherds per herd increased (Pearson correlation, $r=-0.1$ ).

The use of enclosures to keep livestock at night was more common among resident than nomadic pastoralists $\left(\chi^{2}=1.0, \mathrm{df}=1, \mathrm{P}<0.01\right)$. For resident pastoralists the use of enclosures did not change the incidence of predation by all predators. Resident pastoralists that owned enclosures lost a mean of four heads of livestock, similar to a mean of

TABLE 3 Mean livestock losses to predation per household per annum for resident and nomadic pastoralists around Waza National Park (Fig. 1) in 2008, and the resulting probability for a statistical comparison between the two groups of pastoralists.

\begin{tabular}{llll}
\hline & $\begin{array}{l}\text { Resident } \\
\text { pastoralists }\end{array}$ & $\begin{array}{l}\text { Nomadic } \\
\text { pastoralists }\end{array}$ & $\mathrm{P}$ \\
\hline Predation & 1.01 & 1.76 & $<0.01$ \\
Lions on all livestock & 0.92 & 1.83 & $<0.01$ \\
Hyaenas on all livestock & 1.69 & 4.41 & $<0.01$ \\
Jackals on all livestock & 1.85 & 1.37 & $>0.05$ \\
$\begin{array}{l}\text { All predators on all } \\
\text { livestock }\end{array}$ & 4.46 & 7.62 & $<0.01$ \\
\hline
\end{tabular}


five heads per household by those that did not own enclosures. This was different for predation by lions; those that owned enclosures lost one head of livestock compared to two lost by those that did not own enclosures $(\mathrm{P}<0.01)$. Furthermore, the type of enclosure influenced the incidence of predation. Among resident pastoralists that owned enclosures $43 \%(n=99)$ of the enclosures were solid (made of earth) whereas $57 \%$ were weak (made of thorny bushes). The solid enclosures experienced a mean loss of two compared to seven head of livestock per household from the weak enclosures. The use of enclosures by nomadic pastoralists was limited and thus any such losses could not be analysed.

Only $33 \%$ of resident pastoralists owned dogs compared to $53 \%$ of nomadic pastoralists $\left(\chi^{2}=16.4, \mathrm{df}=1, \mathrm{P}<0.01\right)$. The presence of dogs had no significant influence on predation among resident pastoralists. Those that owned dogs experienced a mean loss of five head of livestock compared to four by those that did not own dogs. Nomadic pastoralists who owned dogs experienced a mean loss of six head of livestock whereas those that did not own dogs experienced a mean loss of 10 per household.

When livestock husbandry methods were combined, resident pastoralists that did not practise any form of management experienced a mean loss of four head of livestock compared to three by those that practised at least the three investigated management methods. Those nomadic pastoralists that did not practise any form of management experienced a mean loss of 12 compared to nine head of livestock by those that applied at least the three investigated management methods. Overall, a c. $25 \%$ reduction in livestock depredation was observed with the application of predation management methods (herding by adults, good enclosures and presence of dogs) for both resident and nomadic pastoralists. However, depredation of cattle by lions decreased by $50 \%$ for both pastoralist groups with the three predation management methods applied.

In addition, other local socio-cultural and traditional methods were assumed to deter predators from livestock depredation. Most pastoralists $(70 \%, \mathrm{n}=381)$ believed that reciting certain verses from the Koran would keep predators away from their herds. Fifty-two percent of pastoralists burnt fetish products where they kept livestock during the night. Some technical measures practised locally included the use of fire (40\% of pastoralists) and scarecrows (24\%). Some pastoralists also set up local alarm systems to alert them of the approach of predators at night (40\%). Most pastoralists $(65 \%)$ considered the wind direction when herding livestock to pasture, to avoid lion predation. We did not test any of these methods.

\section{Discussion}

Our findings demonstrate that predation by lions and other predators (hyaena and jackal) is a serious issue in all localities surveyed around Waza National Park, confirming this as a persistent management problem in this area (Bauer \& Kari, 2001; Bauer et al., 2003, 2010; van Bommel et al., 2007). Our study showed that localities west and east of the Park faced intense conflict with predators. Previously Bauer \& Kari (2001) had demonstrated that predation was intense only along the southern boundary of the Park. Recent changes included increased presence of large herds of livestock especially on the western boundary of the Park. Change of the administrative management in 2007 and the subsequent collapse in management of the Park during 2008-2010 contributed to the settlement of pastoralists in this area from neighbouring countries. The situation seems to have been worsened by the drastic decline of the natural prey base (Omondi et al., 2007; Scholte et al., 2007; Foguekem et al., 2010), resulting in large predators depending more on livestock than formerly (De Iongh \& Bauer, 2008).

Economically lions were the most important predator, mainly killing cattle, which have the highest monetary value. Livestock rearing is a major activity and source of income for pastoralists around Waza National Park. It is also a cultural way of life for nomadic pastoralists who sell and utilize dairy products, especially from cattle, for subsistence, passing this asset from generation to generation. The loss of cattle has important economic and cultural consequences. Nomadic pastoralists lost twice as many cattle to predation than did resident pastoralists. This was explained by the fact that they typically owned twice as many cattle. They also seemed to make more intrusions into the Park for water and pasture as well as for social reasons. They perceived that they became famous among their clan when they ventured into the Park and would receive greater acclaim, following release, if they were caught violating Park rules.

The majority of livestock losses took place during the night. Pastoralists, especially nomads, commonly graze their livestock at night from about 22.00 until 02.00. This is to avoid the high temperatures of the day and because of food scarcity (Bauer, 2003). This practice, however, exposes livestock to more predation as lions and hyaenas are more nocturnal (Hayward \& Slotow, 2010). The difference in predation on the herds of resident and nomadic pastoralists could be because of differences in husbandry practices. The use of enclosures to protect livestock at night was more common among resident pastoralists. Nomadic pastoralists were too mobile (Moritz et al., 2010) and considered the building of enclosures time consuming and expensive. This suggests that the building of improved enclosures to protect livestock at night may not be readily adopted as a solution to mitigate depredation of the livestock of nomadic pastoralists.

Predation was similar during the dry and wet seasons. This differs from previous findings that showed predation on 
livestock to be higher during the wet season in this area (Bauer et al., 2003; van Bommel et al., 2007). Our findings were similar to the predation during the dry season described by Scholte (2005). Natural prey in Waza National Park normally congregates at waterholes during the dry season, resulting in temporary residence of lions around these waterholes. It seems now that even during the dry season lions are predating livestock, indicating how scarce wild prey has become. In addition, intrusions into the Park by pastoralists have increased as a consequence of weak protection, resulting in an almost permanent presence of livestock within the Park during the dry season (De Iongh et al., 2009).

Economic losses were higher from disease and theft than from predation but, nevertheless, predation was considered the most serious threat to livestock production, probably because of the conservation attention accorded to predators. The tolerance level of pastoralists and local people to the presence of predators and to conservation seems to have declined compared to the findings of Bauer \& Kari (2001), another indication of a deteriorating situation. Within a year two collared lions were killed by pastoralists in retaliation for livestock depredation (De Iongh et al., 2009; Tumenta et al., 2010).

We identified several husbandry methods in the Waza National Park area but only tested the herding of livestock, use of enclosures and use of dogs. Resident and nomadic pastoralists applied these methods differently to mitigate livestock depredation. Although we based our study on self reporting, which could be biased to some extent, the methods were similar to those described by Ogada et al. (2003), Frank et al. (2005), Packer (2007), Woodroffe et al. (2007) and Bauer et al. (2010). Herding was practised significantly more often by nomadic pastoralists and effectively reduced predation only when herds were accompanied by adults, supporting the findings of Frank et al. (2005) and Packer (2007). Similarly, increasing the number of shepherds per herd reduced predation. Resident pastoralists did not invest much time in herding livestock, probably because they were engaged in other activities such as farming and fishing. This may also explain why most of their herds were accompanied by children. Nomadic pastoralists on the other hand, who always accompanied their livestock, had a propensity to exploit areas where human activities are forbidden and violation punishable by law, including intrusions into the Park for water and pasture. This probably explains the high losses they suffered even though most of their livestock were accompanied by adults.

Strong enclosures significantly reduced livestock losses to all predators, confirming the findings of Frank et al. (2005) and Bauer et al. (2010). This result further underscores the fact that only enclosures with specific characteristics, in this case made of earth rather than thorny bushes, can effectively reduce livestock losses. The majority of enclosures surveyed were made from light Acacia branches and were both weak and porous. Considering the percentage of resident pastoralists that used enclosures, it is possible that this group could adopt the use of improved enclosures to mitigate livestock losses. The presence of dogs during herding and at enclosures did not seem to be effective in reducing predation of the herds of resident pastoralists, contrasting with the findings of Ogada et al. (2003) and Woodroffe et al. (2007). A possible reason could be the fact that dogs in this area are not trained to guard. Our findings revealed that there is no single solution for mitigating livestock depredation around Waza National Park but that a combination of predation management methods appears to be effective.

Livestock predation remains a significant problem around the Park. The reduction of the lion population has mainly been caused by retaliatory killing of lions for livestock depredation (De Iongh et al., 2009; Tumenta et al., 2010). However, the correlation between number of lions killed and livestock depredation requires further investigation (Bauer et al., 2010). For example, are the number of lions killed in the Park a direct reflection of their rate of predation on livestock or do pastoralists have other reasons for killing lions? It would also be of value to carry out a costbenefit analysis of the methods employed to mitigate livestock depredation before advising the adoption of any particular method.

The various methods practised to reduce predation around Waza National Park could provide a basis for mitigation of conflict if applied appropriately by both groups of pastoralists. Education and awareness on the ranging behaviour of lions during different seasons and times of day also needs to be improved for all pastoralists. In addition, the management of the Park needs to improve protection, by organizing more effective patrols, and to introduce penalties for breach of rules. Without such changes, improved enclosures and herding will not stop the retaliatory killing of lions. The lions of Waza National Park have potential to attract tourists to the area. Our findings could be used as a basis to guide park authorities and government and non-governmental organizations in the adoption of solutions to mitigate human-lion conflict around this park. Mitigation methods will need to be tailored according to whether a pastoralist is nomadic or resident and this finding may also be applicable to other protected areas in West and Central Africa.

\section{Acknowledgements}

This research was financially supported by the Institute of Environmental Sciences, Leiden University, The Netherlands, through its collaboration with the Centre for Environment and Development Studies in Cameroon, University of Dschang, Cameroon. We are grateful to the two students from Dschang University who helped to administer the questionnaires. 


\section{References}

Bauer, H. (2003) Lion conservation in West and Central Africa: the case of Waza National Park, Cameroon. PhD thesis, Leiden University, The Netherlands.

Bauer, H., De Iongh, H.H., Princee, P.G. \& Ngantou, D. (2003) Research needs for lion conservation in West and Central Africa. Comptes Rendus Biologies, 326, S112-S118.

Bauer, H., De Iongh, H. \& Sogbohossou, E. (2010) Assessment and mitigation of human-lion conflict in West and Central African. Mammalia, 74, 363-367.

BAUER, H. \& KARI, S. (2001) Assessment of the human-predator conflict with thematic PRA around Waza National Park. PLA Notes, 41, 9-13.

Bauer, H. \& Nowell, K. (2004) Endangered classification of the West African lions. Cat News, 41, 35-36.

Bauer, H., Vanherle, N., di Silvestre, I. \& de Iongh, H.H. (2008) Lion-prey relations in West and Central Africa. Mammalian Biology, 73, 70-73.

Beauvilain, A. (1995) Tableau de la pluviometrie dans les basins du Tchad et de la Benoue de la creation des stations a décembre 1994. Unpublished Report. Centre national d'appui a la recherche, N'Djamena, Chad.

Ben Shahar, R. (1992) Does fencing reduce the carrying capacity for populations of large herbivores? Journal of Tropical Ecology, 9, 249-253.

Bennett, E.L. (2011) Another inconvenient truth: the failure of enforcement systems to save charismatic species. Oryx, 45, 476-479.

B LOM, A. (2001) Ecological and economic impacts of gorilla-based tourism in Dzanga-Sangha, Central African Republic. Doctoral thesis, Wageningen University, The Netherlands.

De Iongh, H.H. \& Bauer, H. (2008) Ten years of ecological research on lions in Waza National Park, Northern Cameroon. CAT News, $48,29-32$.

De Iongh, H., Tumenta, P., Croes, B., Funston, P.J., Bauer, H. \& Udo de HaEs, H. (2009) Threat of a lion population extinction in Waza National Park, North Cameroon. Cat News, 50, 26-27.

Foguekem, D., Tchamba, M.N. \& OMOndi, P. (2010) Aerial survey of Elephants (Loxodonta africana africana), other large mammals and human activities in Waza National Park, Cameroon. African Journal of Environmental Science and Technology, 4, 401-411.

Frank, L.G., Woodroffe, R. \& OGada, M.O. (2005) People and predators in Laikipia District, Kenya. In People and Wildlife: Conflict or Coexistence? (eds R. Woodroffe, S. Thirgood \& A. Rabinowitz), pp. 286-304. Cambridge University Press, Cambridge, UK.

Hayward, M.W. \& Slotow, R. (2010) Temporal partitioning of activity in large African carnivores: tests of multiple hypotheses. South African Journal of Wildlife Research, 39, 109-125.

Henschel, P., Azani, D., Burton, C., Malanda, G., Saidu, Y., SAm, M. \& Hunter, L. (2010) Lion status updates from five range countries in West and Central Africa. CAT News, 52, 34-39.

Mishra, C., Allen, P., McCarthy, T., Madhusudan, M.D., Bayarjargal, A. \& Prins, H.H.T. (2003) The role of incentive programs in conserving snow leopard. Conservation Biology, 17, 1512-1520.

Moritz, M., Soma, E., Scholte, P., Xiao, N., Taylor, L., Juran, T. \& KARI, S. (2010) An integrated approach to modeling grazing pressure in pastoral systems: the case of the Logone Floodplain (Cameroon). Human Ecology, 38, 775-789.

Nyhus, P., Fischer, H., Madden, F. \& Osofsky, S. (2003) Taking the bite out of wildlife damage: the challenges of wildlife compensation schemes. Conservation in Practice, 4, 37-43.

Ogada, M.O., Woodroffe, R., Oguge, N.O. \& Frank, L.G. (2003) Limiting depredation by African carnivores: the role of livestock husbandry. Conservation Biology, 17, 1521-1530.

Omondi, P., Mayienda, R. \& Tснамв A, M. (2007) Total aerial count of Elephants, Giraffes, Roan Antelopes and other wildlife species and Ostrich in Waza National Park, Cameroon. Unpublished Report. WWF Cameroon, Yaounde, Cameroon.

PACKER, C. (2007) Managing African lions to avoid human-wildlife conflicts. In Predator \& Preys: Integrating Management to Achieve Conservation Objectives. North American Wildlife \& Resources Conference Proceedings, Portland, USA.

Packer, C., Brink, H., Kissui, B., Maliti, H., Kushnir, H. \& Caro, T. (2011) Effects of trophy hunting on lion and leopard populations in Tanzania. Conservation Biology, 25, 142-153.

Patterson, B.D., Kasili, S.M., Selempo, E. \& Kays, R.W. (2004) Livestock predation by lions (Panthera leo) and other carnivores on ranches neighbouring Tsavo National Park, Kenya. Biological Conservation, 119, 507-516.

Piran, C.L.W., Jennings, N.V., Renwick, A.R. \& Barker, N.H.L. (2005) Questionnaires in ecology: a review of past use and recommendations for best practice. Journal of Applied Ecology, 42, 421-430.

Scholte, P. (2005) Floodplain rehabilitation and the future of conservation \& development. Adaptive management of success in Waza-Logone, Cameroon. Doctoral thesis. Wageningen University, The Netherlands.

Scholte, P., Adam, S. \& Serge, B.K. (2007) Population trends of antelopes in Waza National Park (Cameroon) from 1960 to 2001: the interacting effects of rainfall, flooding and human interventions. African Journal of Ecology, 45, 431-439.

Treves, A. \& Karanth, U.K. (2003) Human-carnivore conflict perspectives on carnivore management worldwide. Conservation Biology, 17, 1491-1499.

Tumenta, P.N., Kok, J.S., van Rijssel, J., Buij, R., Croes, B.M., Funston, P.J. et al. (2010) Threats of rapid extermination of the lion (Panthera leo leo) in Waza National Park, Cameroon. African Journal of Ecology, 48, 888-894.

Van Bommel, L., de VaAte, M.D.B., De Boer, W.F. \& de IonGH, H.H. (2007) Factors affecting livestock predation by lions in Cameroon. African Journal of Ecology, 45, 490-498.

VAn Dyk, G. \& Slotow, R. (2003) The effects of fences and lions on the ecology of African wild dogs reintroduced to Pilanesberg National Park, South African. African Zoology, 38, 79-94.

Verdade, L.M. \& CAmpos, C.B. (2004) How much is the puma worth? Economic compensation as an alternative for the conflict between wildlife conservation and livestock production in Brazil. Biota Neotropica, 4, 1-4.

Woodroffe, R. \& Frank, L.G. (2005) Lethal control of African lions (Panthera leo): local and regional population impacts. Animal Conservation, 8, 91-98.

Woodroffe, R., Frank, L.G., Linsdsey, P.A., Ole Ranah, S.M.K. \& RomANACH, S. (2007) Livestock husbandry as a tool for carnivore conservation in Africa's community rangeland: a case control study. Biodiversity Conservation, 16, 1245-1260.

\section{Biographical sketches}

Pricelia Tumenta has studied lion ecology and conflict of lions and humans over livestock since 2007 in Waza National Park, Cameroon. Paul Funston is involved with lion conservation research projects throughout Africa, with a current focus on the effects of alien diseases on the lion population in the Kruger National Park. HAN S DE IoNGH has worked on large carnivore research and conservation in West and Central Africa for more than 20 years. Helias Udo De Haes founded the Institute of Environmental Sciences Leiden in 1978. 